\title{
On the Mythical Origin of Yajñopavita
}

\author{
Ankur Betageri \\ University of Delhi, India
}

In this article I explore the act of concealing and embodying esoteric knowledge by considering Vedic, Upanishadic and Puranic narratives concerning the yajñopavitta. The esoteric nature of the initiation ritual of Upanayana established in Vedic texts like Śatapatha-Brâhmana and Atharva Veda is elaborated in the metaphysical Upanishadic texts of Subāla-upanishad and Brahma-upanishad. I show that the yajñopavita, conceptualized as sutra-vastra in the Devānga Purāna, was a symbolic object that concealed and made one embody esoteric knowledge. By considering a similar act of concealing and embodying of the esoteric knowledge that happens while chanting the Samavedic strotas I claim that the yajñopavīta was invented to curb the directedness which comes with the will to knowledge and to symbolically contain the meditative interiority of esoteric knowledge.

Keywords: Yajñopavīta, Upanayana, rite of passage, initiation ritual, Upanishadic discourse, Puranic discourse, Devānga Purāna.

Upanayana is the ritual through which an Aryan boy attains his symbolic second birth and gets the dwija (twice-born) status by wearing the sacrificial cord. This ritual belongs to the class of rituals which have the socio-cultural properties of the liminal period and which Arnold van Gennep has called rites de passage. (Turner 1982: 93) Van Gennep defined rites de passage as 
"rites which accompany every change of place, state, social position and age." (Turner 1982: 94). It is through the rite of passage that an individual is incorporated into the life of the community. Though upanayana appears like puberty initiation, the passage from adolescence to youth, it is actually an initiation ceremony for entrance into brahmacharya (studentship) under a guru, implying a drastic change in the social and ontological status of the individual. The ceremony which begins with a tonsure (a 'sacrifice' of the hair indicating separation from the previous world), a bath, and a change of clothing signifies the death of the former self, and the second birth and incorporation into the secret society of learning. The Śatapatha-Brâhmana which documents the Upanayana rite says, "he who enters on a term of studentship becomes an embryo." (The Śatapatha-Brâhmana 1900: 90) The motif of gestation and rebirth of the student is clearly expressed in the Atharva Veda $(\mathrm{XI}, 5,3)$ where the upanayana is first documented. The word dwi-ja also appears for the first time in Atharva Veda (XIX, I7) to signify someone who has undergone the upanayana. (Eliade 1958: 53) The state of knowing is central to initiation because the initiate is "he who has experienced the mysteries, is he who knows." (Eliade 1987: 189)

Though there is a puberty rite which is performed after a girl's first menstruation and marks the passage from girlhood to womanhood, according to Manu it is marriage which is the equivalent of upanayana initiation for women. (Kane I94I: 292-295)

Upanayana involves the 'correct recitation' of mantras (sacred intoned formulas) before the fire-altar and ends with the binding of the sacrificial cord onto the brahmacharin. The yajñopavīta or sacrificial cord is worn over the left shoulder and is left hanging diagonally across the body to the right hip. Devānga Purāna, which is a commingling of the myths of magical and juridical 
sovereignty and the myths of sovereign-power, offers an interesting narrative about the origin of yajñopavīta. Devānga Purāna, the kula purāna of Devānga- or Deva-Brahmanas, is an early modern text dated to around I532 CE and authored by Bhadra Lingakavi in Telugu. The cultural referentiality of Devānga Purāna, a purāna written in Telugu and subsequently translated into Kannada and Tamil, matches the cosmopolitanism of Sanskrit kāryas and shāstras. Manu, it says, gave birth to jyothi (light) and out of jyothi emerged shakti (force) and out of this force were born the triumvirate of Hindu religion, Brahma, Vishnu, and Shiva, responsible for the creation, sustenance, and dissolution respectively of the cosmos. At the time of their wedding the three gods came stark naked to the seer Devala ', and told him that they needed a producer of 'the cloth of sutra' (sutra vastra), that is, the three-twined yajñopavita worn across the body by the dwijas and the three-verse gāyatri mantra ${ }^{2}$ which is recited during the upanayana ceremony. Devala maharshi then created the sutra vastra and presented them to the three gods at the time of their wedding. ${ }^{3}$ (Shri Devānga Purāna 1978: I-2) Devala who created the materiality of the ritual status of dwijas also showed that the ritual status cannot exist without the non-material element which is upanayana or initiation-ritual through the correct intonation of mantras. (Shri Devānga Purāna 1978: 3)

According to Devānga Purāna, which cites the authority of Subāla-upanishad and Brahmaupanishad, Devala (Deva in the upanishads) is the sutra-brahma, the originator or inventor of sutra, the sacred formula whose material form is the yajñopavita invested with magico-religious character. (Shri Devānga Purāna 1978: 7) Subāla-upanishad, which is reminiscent of the creation hymns Nāsadiya Sukta (X.129) and Purusha Sukta $(X .90)^{4}$ of the Rig Veda, tells the story of origins and the creation of the four orders of society. Subāla-upanishad of Shukla-Yajurveda is a 
response to Raikva's question, "What was at first?" The answer is Parabrahman, the absolute, out of which all things emerged. Out of Parabrahman emerged tamas (darkness), bhutādi (elements), ākāsha (space), vāyu (wind), agni (fire), āpas (water) and prithvi (earth). Then the Parabrahman became a cosmic egg and remained in that form for a year, after which it split into two halves, the upper half becoming the sky and the lower half becoming the earth. In between was the infinite Purusha which was a divine form of many heads, eyes, feet, and hands. This infinite Purusha entered Brahma and out of him emerged the four orders of the society. Purusha then became a Deva and created the Devas. Khanda six of the Subāla-upanishad tells us that the Divine Deva is none other than Deva Narayana, who is "the originator and the ordainer" and also "the agent and the causer of changes." (Thirty Minor Upanishads 19/4: 67-8) It is this Deva-state of Parabrahma-as-Purusha mentioned in the Subāla-upanishad which gets epitomized as Devala or Devānga in the early chapters of Devānga Purāna. (Shri Devānga Purāna 1978: 7) Since Purusha acted as Vishvāmbhara (supporter) by sustaining life on earth through the creation of Rishis, Yakshas, Rākshasās, Gandharvas, wild and domestic animals, and since he also became Vaishvānara (fire) and burnt up all objects leading to the dissolution of prithvi, agni, vāyu, $\bar{a} k \bar{a} s h a$ and indriyas (sense organs) into different elements, and their final merging into tamas (darkness), and then into the supreme Lord, (Thirty Minor Upanishads 19|4: 6I-2) Devala is equated in the Devānga Purāna with the three functions of creation, sustenance, and dissolution of the universe. Dumézil held that mythological narratives contain significant social and cultural realities which are represented in the form of supernatural beings and concepts. Devānga Purāna gives us arresting information, in mythological form, about the structural organization of society. As the puranic narrative progresses Devala becomes more human; we see him as a priest performing sacrificial rites and conferring the upavita, then we see him as the Lord of 
Kings (rajéndra) presenting clothes to the gods and earning laurels and wealth: 'millions of chariots, carts, elephants, horses, palanquins, and servants.' Devala then fights a war with the Daitya (Titan) king Vajradanshtra, is captured, and the Vrishabha (ox) flag given to him by Lord Shankara is taken away from him. Vajradanshtra takes the captured Devala to his kingdom and there he appeases him by various means and proposes that he make a marital alliance by marrying his daughter Padmini. Devala does not agree to this initially but he is forced by Agnideva to marry Padmini and the Vrishabha flag is returned to him. Later, when Devala goes to Kailasa to meet Lord Shankara, he tells him that the temporary loss of Vrishabha flag brought untold suffering to the entire pantheon of gods. And since Devala is responsible for this suffering Lord Shankara curses him to be reborn as a Gandharva (a practitioner of the arts). (Shri Devānga Purāna 1978: 104-105) In this small incident we can see a reflection of what happened in Kalyana in the twelfth century: the Virashaiva movement which led to the mingling of castes through matrimony broke the coalition between the institutions of the state and religious power. This had a negative effect on Vedic religion and its ethos. Though as a Brahmin Devala is entitled to marry a woman from any varna (Shri Devānga Purāna 1978: 120) his marriage to the daughter of the Daitya king is interpreted as social transgression, and since he experiences the social freedom of a Gandharva, he is cursed to be reborn as a Gandharva.

In Brahma-upanishad of Krshna-Yajurveda, sutra is described as "the supreme abode," on it "everything is strung, like beads on the thread." The word yajñopavita is derived from the combination of words, yajña, meaning sacrifice, and upavita, meaning that which surrounds the sacrifice. The sacrificial cord yajñopavita is only a symbol of the sacrificial ceremony. The Sanskrit word Deva (god) is derived from the root div, 'to shine', while the word div means 
heaven. In Brahma-upanishad, Deva is described as the inner mover who is capable of great expansion; he is the esoteric deity who causes one to know, and who thus makes one obtain Brahman, the supreme one and the support of all things. (Thirty Minor Upanishads 19|4: 107)

"Those whose tuft of hair is jñāna, who are firmly grounded in jñāna, and whose yajñopavīta is jñāna, consider jñāna only as supreme." (Thirty Minor Upanishads 19|4: 108) In the ŚatapathaBrâhmana the Guru commits the brahmacharin to Brahman by instructing him to 'sip water' or 'ambrosia' and do his work; he asks him to 'enkindle [his] mind with fire, with holy lustre!' What the upanishad calls the supreme knowledge of Brahman is here an embodied form of knowledge that one attains by sipping, and surrounding oneself with, 'ambrosia'; it is this will to embodied knowledge that the yajñopavita or sacrificial cord envelops.

The yajñopavita, I claim, was invented to curb the will to knowledge (shraddha $\left.{ }^{5}\right)$ and to escape the directedness which comes with this will. It was invented to gain the freedom, impetuosity, bravery, and cheerfulness of life which can only come from intensifying another will, the will to non-knowledge (or the will to forgetting). Freedom from the directedness of the will to knowledge was attained by substituting the will to knowledge that can possess the student (brahmacharin) and the knowledge-seeker with a symbol which represented the will to nonknowledge: the yajñopavitta.

What does the will to non-knowledge mean? One can demonstrate the nature of this will by looking at how the celeritas of Gandharvas ('musicians') enters the space of ritual sacrifice in the ritual chants of Sāmaveda. The melodies of Sāmaveda are so ancient and central to Indian musical culture that Sāmaveda is said to be at the origin of Indian music. The full compass of the 
seven notes of the octave is used to sing the songs of the Sāmaveda. Almost the entire corpus of sāmans or chants of Sāmaveda are basically hymns of Rig Veda set to melodies that are older than the hymns; this means the text of Sāmaveda consists of Rigvedic hymns modified and transformed into chants by being set to older meoldies. Since the melodies of the Sämaveda were selected in the context of the ritual and preexisted the hymns, not all the words of the hymn fit into the melody; when the words don't fit into the melody they are changed and transformed into embellishments with the insertion of sonorous syllables and meaningless musical sounds called stobha.

Ritual chants are central to Sämaveda. Strotas or stutis which are songs of 'praise' are the most famous of the ritual chants. The strota contains five sections: the Prastāva (prelude), the Udgita (main theme or chant), the Pratihāra (the first response), the Upadrava (the second response) and the Nidhāna (final chorus). The three Samavedic priests, Prastotar, Udgatar and Pratihārtar are named after the first three sections of strota: Prastāva, Udgīta and Pratihāra. The sacrificial singing of the Sāmavedic strotas begins with the hoonkara, the singing of the syllable 'hoom,' and ends with the Pranava, the chanting of the syllable om. The Prastāva is sung by the assistant priest, Prastotar facing west; the UdgIta and Upadrava by the chief priest, Udgatar, (only the Udgita is sung facing north), and the Pratihāra by the assistant priest, Pratihōrtar facing south. The Hoonkara, Nidhāna and Pranava are sung by all the priests together.

The basis of Sāmavedic chanting is a hymn addressed to Soma from Rigveda: upāsmai gāyatā narom. ('Gentlemen! Join us in chant to him!'). The chanting of the strota which contains five 
sections begins with the text of the first section, Prastāva, but the subsequent four portions of the song (Udgīta, Pratihāra, Upadrava and Nidhāna) are changed or transformed by the chanting of meaningless syllables or sounds which hide the original verse. This kind of chanting is made possible by breaking up words, lengthening the vowels beyond recognition, and inserting meaningless syllables. The text of the song which is sung is called nirukta ('expressed') and the text hidden by the sounds is called aniruktagāna, 'unexpressed chant.' It is called so because the singer is supposed to think of the hidden text of the song while singing the meaningless syllables. The musical non-knowledge of Gandharvas enters the space of ritual sacrifice by projecting the vigour, speed, and musicality of sound as central to the performance and by hiding the text of the song. But while the text of the song is being hidden by the sonorous sounds and meaningless syllables one thinks of the text (a central idea, an image, or an affect illuminating the text) thus embodying the mystery and esoterism present in the strota.

It is vocal chanting which gives meaning to the symbol of yajñopavita by consecrating it; through consecration this object of the common world enters the domain of religion. When I say the yajñopavita intensifies the will to non-knowledge I see the yajñopavitta as analogous to the technique of chanting the strotas of Sämaveda in which the chanting hides the text of the song. Yajñopavīta is the symbolic materiality whose expression conceals esoteric knowledge and makes one embody it just as the expressed Sāmavedic chant conceals and makes one live the meditative interiority of esoteric thought. 


\section{End notes}

${ }^{1}$ Devala is the progenitor of Devānga Brahmanas. In the Devānga Purāna, he is described as Brahma, the original source of all things. But he can be compared with Odin, the /Esir god, as he is both Manu (first priest) as well as a sovereign. (Shri Devānga Purāna, 1978: 2, 3, 4I; Dumézil 1973: 4, 18)

${ }^{2}$ The Gayatri mantra (Rig Veda III.62.10) begins with om bhur bhuva svaha, but the three verses of eight syllables which are recited during the upanayana ceremony are: tat savitur varenyam/ bhargo devasya dhimahi / dhiyo yo nah prachodayāt.

${ }^{3}$ Three sutras or upavitas are to be bound on the dwijas. The first during upanayana, the second during marriage, and the third is to be worn as uttariya. Women are to be given the sutra during marriage as manngalya, marriage necklace. (Shri Devānga Purāna 1978: 66)

${ }^{4}$ The dismemberment of the cosmic giant Purusha to create the world, narrated in the Purusha Sukta, is similar to the dismemberment of the Norse frost-giant Ymir. While the representation of the divine are elaborated in the myths, they only preserve traces of their origin. "A sacrifice in more or less distorted form constitutes the central episode and, so to speak, the heart of the legendary life of gods that arose from sacrifice." (Hubert and Mauss 1964: 82)

${ }^{5}$ Shraddhā is devotion; the philological equivalent is the Latin credo, literally 'to put one's heart'.

\section{References}

Atharva Veda Samhita. 1987. Trans. by M. Bloomfield. Oxford.

Aufrecht, T, ed.I877. Rg Veda Samhita. 2 Vols. Bonn. 
Caland, W, ed. 1907. Sama Veda (Jaiminiya). Breslau.

Dumézil, Georges. 1973. Gods of Ancient Northmen, ed. Einar Haugen. Berkeley: University of California Press.

Eliade, Mircea. 1958. Rites and Symbols of Initiation: The Mysteries of Birth and Rebirth. Trans. Willard R Trask. New York: Harper and Row.

Eliade, Mircea. 1987. The Sacred and the Profane: The Nature of Religion. Trans. Willard R. Trask. New York: Harcourt, Brace \& World.

Hubert, Henri and Marcel Mauss. 1964. Sacrifice: Its Nature and Functions. Trans. W.D. Halls. Chicago: The University of Chicago Press.

Kane, P.V. 1930-1962. History of Dharmashastra. 5 Vols. Poona: BORI.

Sastri, Pt. Hargovinda, ed. 1982. Manu Smrti. With Kulluka Bhatta's commentary. Varanasi: Chaukhamba Sanskrit Sansthan.

Shri Devānga Purāna. 1978. ed. Devanga Purāna Sampadaka Mandali. Bengaluru: Devanga Sangha.

Staal, Fritz. 2013. Discovering the Vedas: Origins, Mantras, Rituals and Insights. New Delhi: Penguin Books.

Sturluson, Snorri. 2005. The Prose Edda. Trans. Jesse L. Byock. London: Penguin Books.

The Rigveda: Vols I, II and III. 2014. Trans. Stephanie W. Jamison and Joel P. Brereton. Oxford: Oxford University Press.

The Rig Veda: An Anthology. 2014. Trans. Wendy Doniger O'Flaherty. Gurgaon: Penguin Books.

The Śatapatha-Brâhmana. 1900. Trans. Julius Eggeling. 5 Vols. Oxford: The Clarendon Press.

Thirty Minor Upanishads. 1914. Trans. K. Narayanasvami Aiyar. Madras. 
Turner, Victor. 1982. The Forest of Symbols. Ithaca: Cornell University Press.

Van Gennep, Arnold. 1960. The Rites of Passage. Trans. Monika B. Yizedom and Gabrielle Caffee. Chicago: The University of Chicago Press. 